\title{
An empirical investigation of the relationship between market orientation and MrkIS effectiveness in upscale hotels in Greece
}

Received (in revised form): 17th August, 2008

\section{Kalliopi C. Chatzipanagiotou}

is an adjunct lecturer in marketing in the Department of Business Administration of the Athens University of Economics and Business (AUEB). She received her $\mathrm{PhD}$ in marketing from $\mathrm{AUEB}$, Athens. Her research interests are in the areas of marketing information systems, services marketing, retail marketing and tourism.

\begin{abstract}
Aikaterini Vassilikopoulou
is an adjusted lecturer in marketing at AUEB. She holds a BSc in business administration from AUEB, an MSc in economic psychology from the University of Exeter, an MBA from the National Technical University of Athens and AUEB and a PhD in marketing from AUEB. Her research interests include business ethics, corporate social responsibility and consumer behaviour.
\end{abstract}

\section{George J. Siomkos}

is a professor of marketing and ex-Chairman of the Department of Business Administration at AUEB. He has taught at the Stern School of Business, New York University, Long Island University and University of Macedonia. He has worked as a research associate at the Industrial Crisis Institute of New York. He holds a BSc (Hons) in marketing and management, an MBA in finance, an MSc in statistics and operations research, an MPhil in marketing and $\mathrm{ahD}$ in marketing and corporate strategy from the Stern School of Business, New York University. He has published over 70 papers in academic journals.

Keywords marketing information systems effectiveness, market orientation, canonical correlation

\begin{abstract}
This study examines the nature of relationships between marketing information systems (MktIS) effectiveness and market orientation (MO) dimensions. The study utilises a canonical correlation approach in order to determine the relationship between the two constructs. The results indicate that $\mathrm{MO}$ and MrkIS effectiveness are related concepts. More interesting is the relationship of customer and competitor orientation, especially with the external dimensions of the MrkIS effectiveness. These are the first empirical data that demonstrate a strong relationship between the customer and competitor orientation dimensions of the MO concept with the marketing procedural improvement and the two external dimensions of MrkIS effectiveness, namely customer knowledge and market responsiveness. On the other hand, interfunctional coordination is more closely related to internal climate of company's MrkIS effectiveness. Based on the results, managerial implications are discussed. Limitations of the study as well as future research directions are also addressed.
\end{abstract}

Journal of Targeting, Measurement and Analysis for Marketing (2008) 16, 285-297. doi:10.1057/jt.2008.20;

published online 10 November 2008

\section{INTRODUCTION}

The modern competitive environment is characterised by globalisation, numerous

Correspondence: Kalliopi C. Chatzipanagiotou, Department of Business Administration, Athens University of Economics and Business, 76 Patission Street, Athens 104-34, Greece.

Tel: + 302108203712 ;

Fax: + 302108203712 ;

E-mail: khatzip@aueb.gr homogeneous products and services, alternatives distribution channels and many communication technologies. In this competitive environment, managers try to find new sources to obtain a competitive advantage. In this direction, the utilisation of the marketing information systems (MrkIS) is essential for the company in order to compete and survive in such a competitive marketplace. ${ }^{1-4}$ 
Many researchers in the field of information technology and marketing have discussed the advantages of the adaptation and the use of IS in marketing. ${ }^{1-11}$ In addition, in the literature there are numerous studies focusing on the factors affecting MrkIS effectiveness.

Many researchers have stressed the role of market orientation (MO) as one of the most crucial factors affecting MrkIS effectiveness. ${ }^{2,4,12}$ Despite the fact that the relationship between MO and MrkIS effectiveness has been pointed out in the literature, there are still unresolved issues concerning the conceptualisation and the true nature of the relationship between the two constructs. $^{2,12}$

Hence, the purpose of this paper is to empirically examine the nature of the relationship between MO and the effectiveness of MrkIS. The structure of the paper is organised as follows: first, we review the relevant literature to define MrkIS effectiveness as well as the MO notion, in order to develop the research proposition of our study. Next, we present the methodology and the results of the empirical study providing implications for managers. Finally, the limitations of the study and the suggestions for future research are also addressed.

\section{LITERATURE REVIEW}

\section{MrkIS effectiveness}

The first definition of MrKIS, presented in 1967, determines these types of systems as a set of procedures and methods for analysing, planning and presenting information required in taking marketing-related decisions. ${ }^{13}$ In the following decades, researchers presented many MrkIS sub-systems such as marketing intelligence systems, marketing research systems, marketing decision support systems, marketing planning systems sales productivity and support systems and so on, in order to categorise these systems and investigate their usefulness in the specific marketing fields. The purpose of the earliest MrkIS was to gather, analyse, evaluate, organise and distribute timely, relevant and accurate information for marketing decision makers. ${ }^{14}$

Although the benefits of these kinds of systems have been mentioned by many researchers in the literature, the examination of the notion of MrkIS effectiveness remains a major 'unknown' issue.

The concept of effectiveness could be defined as the power of capacity needed in order to deliver a required result. ${ }^{15}$ In other words, effectiveness includes the notion of success, as being effective indicates the completion of the outcomes that had been arranged.

The MrkIS effectiveness notion, as Gounaris et al. ${ }^{16}$ mentioned, is a complex construct, which comprises various facets, ${ }^{16}$ such as, among many others, efficiency, productivity, flexibility, control, internal communication and information management. In order to get a more integrated definition, we have to demarcate two major dimensions of the MrkIS effectiveness construct ${ }^{16}$ : (a) the internal dimension (ie the improvement of the marketing operational procedures and the internal climate as defined by the relationships between the marketing department and its employees) and (b) the external dimension (ie the company's responsiveness in terms of financial and nonfinancial performance).

The internal dimensions of MrkIS effectiveness refer to the utilisation of procedures and methods of MrkIS in order to improve the decisionmaking process, $3,4,14,18-22$ reporting, ${ }^{23}$ planning/ implementation ${ }^{3,8,14,18,21,24,25}$ and control of marketing actions. ${ }^{3,14}$ Another important aspect of the MrkIS internal dimensions relates to the human factor, and the management of the company's internal relationships. By allowing more employees and departments to share and handle information, MrkIS offers unprecedented flexibility, communication and convenience. Employees can get reports out quicker, define executable actions, create measurable deliverables and clarify roles and responsibilities. Thus, ITbased MrkIS can help hotels to improve internal communication between colleagues in the marketing department and other functional units because communication becomes easier and faster. ${ }^{1,14}$

As a result, MrkIS increases the amount of information that managers can access and handle. Consequently, provided the proper decision support and analysis tools are available, managers can improve their decisions. ${ }^{4}$ Thus, managers 
improve their marketing planning activities, remove non-value-added activities and improve process flow and corporate efficiency. MrkIS also helps marketing managers to establish clear marketing goals with metrics and key deliverables (reports) to ensure that marketing employees can deliver any marketing project within the scope, schedule and resource targets. In this way, managers use a variety of MrkIS tools to understand the needs of the marketing employees while clarifying to the employees what is expected from them and their roles in the company's marketing strategy. Therefore, MrkIS applications lead the marketing team to identify specific concerns, determine which have the highest priority and create an action plan to resolve these concerns.

Concerning the external dimensions of MrkIS effectiveness, many researchers stress that through their MrkIS companies, they have the opportunity to improve customer knowledge, ${ }^{10,21,26}$ marketing programme efficiency ${ }^{27-30}$ and market responsiveness. ${ }^{3,31,32}$ In other words, MrkIS facilitates the identification of consumer needs, which, in turn, allows managers to develop more 'suitable' new products and in this way to build a more effective product-market strategy that includes an outline of any adjustments necessary to fulfill the needs of customers and meet market demands. Thus, the new product development and/or modification is reinforced and becomes more effective. ${ }^{18,26,33}$ In addition, by building up a strong body of customer knowledge, the company can build and manage customer relationships now and in the future, in terms of more satisfied and loyal customers. ${ }^{34}$

Furthermore, the identification of customers' present and future needs could also increase the market share. ${ }^{18}$ The MrkIS benefits mentioned above contribute to the reduction of marketing costs, since the valuable information managers capture for their systems help them, for instance, to understand where they have cross-sale and upsale opportunities, or to understand what type of customers are the most profitable. In addition, this kind of information helps the marketing managers to decide what to offer, when to offer it and for how much. Likewise, the profound analysis of market trends and customers' media habits leads to more efficient targeting of the communication effort and strengthens the allocation of the communication budget. On top of this, direct marketing activities become more resourceful. ${ }^{35}$ Such cost savings are connected to profitability increase. ${ }^{8,10}$

\section{Market orientation}

MO became a 'hot' topic in marketing literature nearly a decade ago. ${ }^{36-41}$ The marketing literature reflects a variety of definitions of MO. ${ }^{36,38,42-44}$ One research stream stressed the cultural nature of the MO concept. ${ }^{38,43,45}$ They mentioned that $\mathrm{MO}$ is a system of corporate beliefs and values that enables the creation of superior customer value and shapes the company's internal environment and climate so that it can be responsive to market information.

On the other hand, the publication of two almost parallel studies, Narver and Slater's ${ }^{36}$ and Kohli and Jaworski's, ${ }^{42}$ constituted the cornerstone of $\mathrm{MO}$ behavioural conceptualisation. According to Kohli and Jaworski, ${ }^{42} \mathrm{MO}$ is an organisation-wide generation of market intelligence related to current and potential customer needs. In addition, MO is related to dissemination of intelligence across departments as well as the appropriate organisation responsiveness to impending market needs.

Narver and Slater, ${ }^{36}$ who basically agree with Kohli and Jaworski, ${ }^{42}$ encourage three main aspects of MO: (a) customer orientation (ie understanding of the current and future customer's needs, preferences and special characteristics), ${ }^{46}$ (b) competitor orientation (ie ability to understand the short-term strengths and weaknesses as well as long-term abilities and strategies of both current and future competitors) $)^{46-49}$ and (c) the coordination of the partial departments and functions of a company.

Slater and Narver (1995), however, introduce the cultural dimension of MO. They argue that $\mathrm{MO}$ is a business culture in which all employees are committed to the continuous creation of greater value for customers. ${ }^{50}$ According to their study, it is crucial for organisations to recognise $\mathrm{MO}$ as an original part of their culture. 
The scales that Kohli and Jaworski ${ }^{42}$ and Narver and Slater ${ }^{36}$ created have been tested, validated and improved as presented in the relevant literature. ${ }^{39,51,52}$ Nevertheless, the Kohli and Jaworski ${ }^{42}$ construct incorporates cultural factors ${ }^{38,53}$ and mainly focuses on marketing orientation instead on $\mathrm{MO} .{ }^{54}$ Thus, in the current study, the Narver and Slater ${ }^{36}$ definition was preferred.

\section{MO and MrkIS effectiveness}

Based on the previous discussion of MO nature, it would be reasonable to conclude that all interpretations of $\mathrm{MO}$ have an operational focus in market information processing activities. ${ }^{55}$ In any case, the acquisition, distribution, interpretation and storage of market information are considered weapons for a company to use in order to cope with uncertain and competitive environment.

In this way, companies can deal with a competitive environment by increasing their information processing capability enabled by MrkIS. In other words, the market-driven organisations know their markets so thoroughly that they are able to identify and utilise MrkIS applications in order to offer superior solutions to customers, find and retain employees, anticipate competitor's moves and gain revenue growth. ${ }^{12}$ Through the automation of the collection, filing, processing and diffusion of consistently correct information, a company is able to make the right decisions and to intensify its efforts to be oriented towards the customer and the customer's special features, as well as towards the competitor and the competitor's strategic movement.

On these grounds, the major research hypothesis we investigate in this paper is as follows:

RH: MO dimensions (customer orientation, competitor orientation and interfunctional coordination) are related to MrkIS effectiveness dimensions.

\section{METHODOLOGY}

\section{Sample and data collection}

The data presented in this paper are part of a broader study, of luxury and 5-star hotels in
Greece. The current study focuses only on luxury and 5-star hotels. This decision is based on the results of earlier desk research. Many researchers indicated that relatively smaller hotels, if and when employing IT-based information systems, did so to a minimum and only at operational level (eg for accounting and billing purposes), while lacking any degree of integration of their information system. ${ }^{28,56-58}$

In order to increase the content validity of the research instrument, 77 personal interviews were conducted with managers who agreed not only to fill in the questionnaire, but also to comment on the scales employed (pilot study).

Consecutively, in order to collect the data, the ICAP Directory, ${ }^{59}$ which identified 780 hotels classed as luxury and 5 stars, was consulted, and self-filling questionnaires were addressed and mailed to hotel marketing managers. Given the relatively small research population, the authors decided to do a census rather than draw a sample. Hence, the research instrument was mailed to all 7805 -star hotels. Two mailing waves produced 254 usable questionnaires (response rate 35 per cent).

With regard to potential nonresponse bias, there are various ways to examine whether nonresponse represents a problem. Examining and comparing the study's response rates with those of an earlier study, comparing sample and frame estimates and comparing the findings of the study with those from external sources are some approaches that allow direct statistical control of the bias that nonresponse may have introduced in the findings. ${ }^{60}$ These direct approaches are not, however, applicable in the case of this study because there is no precedent study or any external data that could serve as a comparison basis. Hence, to test the possible impact of nonresponse bias, the suggestions of Armstrong and Overton ${ }^{61}$ were followed and the authors divided all returned samples into two groups: early respondents who returned their survey before the follow-up call, and late respondents who returned their survey after the follow-up call. This type of extrapolation approach is the most widely adopted one in estimating possible nonresponse bias because late respondents resemble quite closely the profile of 
nonrespondents. The authors compared the averages and standard deviations of relevant variables between these two groups to ascertain whether there were any significant differences. The results indicate that nonresponse does not influence the results of this study.

\section{Variables measurements}

The MrkIS effectiveness scale is specifically based on the work of Sääksjärvi and Talvinen ${ }^{14}$ and Gounaris et al. ${ }^{16}$ Respondents were asked to use a seven-point scale (anchored 1='I strongly disagree' to $7=$ 'I strongly agree') and to indicate their agreement with each item.

The first phase of the analysis utilised exploratory factor analysis (EFA), to derive a preliminary factorial structure of the measure, ${ }^{62}$ and four confirmatory factor analyses (CFAs) to assess the unidimensionality of the four partial constructs. The total sample was accordingly divided randomly in half; an EFA was run on the first data subset and CFAs on the second.

Table 1 summarises the result from EFA, which produced four factors: (a) the marketing procedural improvements, (b) the marketing employees support, (c) the adaptation and the knowledge of its market - customer's knowledge and (d) its goals and corporate objectives achievement - market responsiveness. In total, the four-factor solution explains 82.6 per cent of the total variance of the initial variables. The results of EFA provide us with the first evidence for the unidimensionality of the partial constructs, while indicators have higher factor loadings on their own constructs than on other constructs.

The next stage of analysis involved four CFAs to assess the unidimensionality of the four partial constructs. The results of the four CFAs provide evidence of the goodness-of-fit in all partial constructs. Before the overall construct of MrKIS effectiveness was accepted, however, the resulting set of items was tested for unidimensionality and convergent and discriminant validity using CFA. Fornell and Larcker ${ }^{63}$ provide a procedure for assessing convergent and discriminant validity, which depends on the average variance extracted (AVE) for each of the core dimensions examined in the CFA.
The result of CFA, showing a very good fit with the data, concludes that the indicators adequately measure the intended constructs and provide further evidence for the unidimensionality of the overall MrkIS construct. The convergent and discriminant validity for the MrkIS construct, as can be seen from the results of Table A1, are at an acceptable level for Convergent (AVE $>0.50$ in all occasions) and Discriminant (AVE is greater than or equal to unity in all occasions) validity. ${ }^{64,65}$ In the final stage of analysis, a three- and a two-factor model of MrkIS effectiveness were also tested. A chisquare test of both models with the four-factor model suggested the acceptance of the four-factor construct. Once unidimensionality was established, internal consistency was calculated using Cronbach's alpha. ${ }^{66}$

Many MO scales have been tested and refined in the literature. ${ }^{36-39,42,64,67}$ For instance, Hooley et al. ${ }^{37}$ saw $\mathrm{MO}$ as the implementation of the marketing concept, but limited their investigation to differences between companies with dominant marketing, sales or production orientations. Kohli and Jaworski ${ }^{42}$ considered MO in terms of market scanning, information sharing and response activities. Deshpande et al. ${ }^{38}$ considered it to be a culture, but three competing scales were reduced down to a common customer orientation dimension.

Although Narver and Slater ${ }^{36}$ conceptualised $\mathrm{MO}$ as a culture, they tended to measure its implementation, using both attitudinal and behavioural scales. ${ }^{68}$ One of their major contributions was to broaden the original marketing concept to include customer needs and competitor actions as well as a strategic focus. In addition, Narver and Slater's scale is the most widely adopted, since it has tended to dominate MO studies in most countries. Thus, in order to measure MO, Narver and Slater's ${ }^{36}$ scale was used. According to this instrument, $\mathrm{MO}$ comprises three basic elements: (1) customer orientation, (2) competitor orientation and (3) interfunctional coordination. Respondents were asked to use a seven-point scale (anchored 1 ='I strongly disagree' to 7 ='I strongly agree') and to indicate their agreement with each item. The reliability of 
Table 1: Exploratory factor analysis of the hotels MrkIS effectiveness dimensions

\begin{tabular}{|c|c|c|c|}
\hline Factors produced by the analysis & Items loading on each factor & Loadings & $\begin{array}{l}\text { Cronbach's } \\
\text { alpha }\end{array}$ \\
\hline $\begin{array}{l}\text { Factor 1: Marketing procedural } \\
\text { improvement (explaining } 27 \text { per cent } \\
\text { of total variance) }\end{array}$ & $\begin{array}{l}\text { Improved marketing efforts control } \\
\text { Improved marketing actions planning } \\
\text { Improved marketing reporting } \\
\text { Improved marketing decision making }\end{array}$ & $\begin{array}{l}0.89 \\
0.68 \\
0.89 \\
0.68\end{array}$ & 0.835 \\
\hline $\begin{array}{l}\text { Factor 2: Marketing employees support } \\
\text { (explaining } 26 \text { per cent of total } \\
\text { variance) }\end{array}$ & $\begin{array}{l}\text { Time saving, lower level of marketing routine work } \\
\text { Improved sales work and customer service } \\
\text { Improved internal communication }\end{array}$ & $\begin{array}{l}0.74 \\
0.98 \\
0.66\end{array}$ & 0.831 \\
\hline $\begin{array}{l}\text { Factor 3: Hotel's customer knowledge } \\
\text { (explaining } 22 \text { per cent of total } \\
\text { variance) }\end{array}$ & $\begin{array}{l}\text { Improved market sensitivity } \\
\text { Improved customer satisfaction } \\
\text { Improved sales } \\
\text { Improved customer knowledge }\end{array}$ & $\begin{array}{l}0.65 \\
0.59 \\
0.59 \\
0.82\end{array}$ & 0.925 \\
\hline $\begin{array}{l}\text { Factor 4: Market responsiveness } \\
\text { (explaining } 7 \text { per cent of total } \\
\text { variance) }\end{array}$ & $\begin{array}{l}\text { Marketing programmes cost savings } \\
\text { Quickest development of new services in the market } \\
\text { Improved sales promotion activities } \\
\text { Direct and more effective marketing research }\end{array}$ & $\begin{array}{l}0.71 \\
0.75 \\
0.79 \\
0.86\end{array}$ & 0.937 \\
\hline
\end{tabular}

Kaiser-Meyer-Olkin measure of sampling adequacy: 0.896 , Bartlett's test of sphericity: $\chi^{2}=4210.84$ significant 0.000 .

Total variance explained: 83 per cent.

the measurement was reinvestigated using Cronbach's alpha. On all occasions, the calculated coefficient well exceeded the minimum acceptable level (minimum value of $\alpha=0,727$ and maximum value of $\alpha=0,823$ ) and thus, additive scales were developed. ${ }^{66}$

\section{DATA ANALYSIS}

To investigate this research hypothesis, a multivariate analytic approach was adopted. More specifically, a canonical correlation analysis to identify potential relationships and existing variates between the two sets of variables was employed. ${ }^{69,70}$ Canonical correlation analysis examines the independent statistical relationships that exist between two variable sets by analysing the sets simultaneously and identifying and quantifying the elements of one variable set most highly related to the elements of the other variable set. ${ }^{70,71}$ The advantage that canonical correlation has over typical multiple regression is that it can take into account the complex nature of data: multiple regression is used for many-to-one relationships, canonical correlation is used for many-to-many relationships. The MANOVA procedure in the Statistical Package for the Social Sciences (SPSS) was utilised to run the canonical analysis. $^{72}$

Canonical correlation begins with two sets of data: (a) MO: customer orientation, competitor orientation and interfunctional coordination (as independent set) and (b) MrkIS: marketing procedural improvements, marketing employees support, customer knowledge and market responsiveness (as dependent set).

Table 2 provides alternative tests of significance. The small $p$-values for these tests $(<0.05)$ suggest rejecting the null hypothesis that all canonical correlations are zero.

The ratio of the eigenvalues, as shown in Table 3, is the ratio of the explanatory importance of the three canonical correlations (labelled 'roots') that are extracted for these data. As usual, the first canonical correlation is far more important than the others.

As shown in Table 3, the first canonical correlation the 'covariate' canonical variable explains about 35.5 per cent $(0.596 \times 0.596)$ of the 
Table 2: Multivariate tests of significance and approximate $F$-tests

\begin{tabular}{llllll}
\hline Test name & Value approx. & $\boldsymbol{F}$ hypothesis & d.f. & Error d.f. & Significance of $\boldsymbol{F}$ \\
\hline Pillais & 0.12992 & 2.81777 & 12 & 747.00 & 0.000 \\
Hotellings & 0.14016 & 2.86945 & 12 & 737.00 & 0.000 \\
Wilks' lambda & 0.87381 & 2.84499 & 12 & 653.79 & 0.000 \\
Roys & 0.08747 & & & & \\
\hline
\end{tabular}

Table 3: Eigenvalues and canonical correlations

\begin{tabular}{lllrll}
\hline Root no. & Eigenvalue & Pct. & Cum. Pct. & Canon Cor. & Sq. Cor \\
\hline 1 & 0.364 & 88.387 & 88.387 & 0.596 & 0.355 \\
2 & 0.134 & 11.469 & 99.856 & 0.366 & 0.133 \\
3 & 0.000 & 0.144 & 100.000 & 0.014 & 0.000 \\
\hline
\end{tabular}

Table 4: Dimension reduction analysis

\begin{tabular}{llllll}
\hline Root no. & Wilks lambda & $\boldsymbol{F}$ hypothesis & d.f. error & d.f. & Significance of $\boldsymbol{F}$ \\
\hline 1 & 0.87381 & 2.84992 & 12 & 653.79 & 0.001 \\
2 & 0.95756 & 1.81198 & 6 & 496.00 & 0.004 \\
3 & 0.99980 & 0.02517 & 2 & 249.00 & 0.975 \\
\hline
\end{tabular}

variance in the dependent canonical variable. Similarly, in the second canonical correlation, the 'covariate' canonical variable explains only about 13.3 per cent $(0.366 \times 0.366)$ of the variance in the dependent canonical variable. Furthermore, the significance of the F-test in Table 4 shows that the two canonical correlations are significant $(p<0.05)$ but the three are not. Thus, only the two canonical correlations are significant and only the two pairs of canonical variables need to be identified. In general, the researcher faces the choice of interpretation of the functions using canonical weights (standardised coefficients) and canonical structure loadings or canonical crossloadings. Given a choice, it is felt that crossloadings are superior to loadings, which are in turn superior to weights. ${ }^{73}$

The canonical factor loading is the correlation of a canonical variable with the original variable in its set. In other words, the canonical factor loadings show how the original variables load on each of the canonical variables for the dependent set of variables in the two canonical correlations. Our largest loadings for the first correlation (Table 5) for MrkIS effectiveness are customer knowledge and market responsiveness, and for $\mathrm{MO}$ are customer and competitor orientation. The dimension of marketing procedural improvements also has relatively large loading. Note that marketing employees support does not seem important in the relationship of these sets of variables.

For the second correlation, our largest loadings for MrkIS effectiveness are marketing procedural improvements and marketing employees support and for $\mathrm{MO}$ is interfunctional coordination. The other dimensions of MO (customer and competitor orientation) have very low loadings.

Table 5 also includes the cross-loadings for the two canonical functions. In studying the first canonical function, it can be seen that the independent variables company's customer knowledge (0.644) and market responsiveness (0.560) exhibit high correlations with the independent canonical variate. This reflects the high-shared variance between these two variables. By squaring these terms, it is found that the percentage of the variance for each of the variables is explained by canonical correlation 1 . The results show that 41.4 per cent of the variance in company's customer knowledge and 31.3 per cent of the variance in market responsiveness is explained by the first canonical correlation. Looking at the independent variables' cross-loadings, demonstrates that the variables customer orientation (0.520) and competitor 
Table 5: Canonical loadings and canonical cross-loadings

\begin{tabular}{|c|c|c|c|c|}
\hline & \multicolumn{2}{|c|}{ Canonical loadings } & \multicolumn{2}{|c|}{ Canonical cross-loadings } \\
\hline & 1 & 2 & 1 & 2 \\
\hline MrkIS effectiveness & \multicolumn{4}{|c|}{ Set 1 (dependent variables) } \\
\hline Marketing procedural improvement & 0.467 & 0.404 & 0.387 & 0.243 \\
\hline Marketing employees support & 0.016 & 0.467 & 0.160 & 0.375 \\
\hline Hotel's customer knowledge & 0.969 & 0.068 & 0.644 & 0.014 \\
\hline Market responsiveness & 0.880 & 0.016 & 0.560 & 0.063 \\
\hline Market orientation & \multicolumn{4}{|c|}{ Set 2 (independent variables) } \\
\hline Customer orientation & 0.676 & 0.023 & 0.520 & 0.005 \\
\hline Competitor orientation & 0.881 & 0.095 & 0.560 & 0.019 \\
\hline Interfunctional coordination & 0.233 & 0.832 & 0.158 & 0.471 \\
\hline
\end{tabular}

orientation (0.560) have high correlations with the dependent canonical variate. The correlation of interfunctional coordination (0.158) appears low, and after squaring this correlation, only the 2.4 per cent of the variation is included in the canonical variate. Thus, the first canonical variable seems to capture mainly company's customer knowledge, market responsiveness and marketing procedural improvements as explanatory variable, with customer and competitor orientation. This result of the first canonical correlation underlines the fact that customer and competitor orientation were significantly related to the external dimensions of MrkIS effectiveness and slightly with marketing procedural improvements. The correlation of interfunctional coordination (0.158) appears low, and after squaring this correlation, only the 2.4 per cent of the variation is included in the canonical variate. Similar statements could be made about the second canonical correlation. In studying the second canonical function, it can be seen that the independent variable marketing employees support (0.375) exhibits high correlation with the independent canonical variate. Looking at the independent variables' cross-loadings, show that the variable interfunctional coordination (0.471) has high correlation with the dependent canonical variate. This result of the second canonical correlation underlines the fact that interfunctional coordination was significantly related to the marketing employees support.

The final issue of interpretation is examining the signs of the cross-loadings. All independent and dependent variables have a positive relationship. Similarly, for the second canonical correlation, all independent variables have a positive relationship.

The authors use canonical correlation coefficients to test for the existence of overall relationships between sets of variables; but for a measure of the magnitude of relationships, redundancy is more appropriate. ${ }^{74}$ This index provides a summary measure of the ability of a set of independent variables to explain variation in the dependent variables. As such, the redundancy measure is perfectly analogous to multiple regression's $R^{2}$ statistic, and its value as an index is similar. ${ }^{73}$

In other words, redundancy analysis is used to measure whether the dependent canonical variable predicts the values of the original independent variables, how well the independent canonical variable predicts the values of the original independent variables and how well the dependent canonical variable predicts the values of the original dependent variables.

To this end, Table 6 shows that, for the first canonical correlation, the independent canonical variable is able to predict 27.4 per cent of the variance in the individual original dependent variables. Also, the dependent canonical variable predicts 50.5 per cent of the variance in the individual original dependent variables. Similar statements could be made about the second canonical correlation.

Finally, for the first and second canonical correlations, the independent canonical variables are able to predict 45.4 per cent of the variance 
Table 6: Canonical redundancy analysis

\begin{tabular}{|c|c|c|c|c|}
\hline & \multicolumn{2}{|c|}{$\begin{array}{l}\text { Their own } \\
\text { Canonical variables }\end{array}$} & \multicolumn{2}{|c|}{$\begin{array}{l}\text { The opposite } \\
\text { Canonical variables }\end{array}$} \\
\hline & Proportion (\%) & $\begin{array}{l}\text { Cumulative } \\
\text { proportion (\%) }\end{array}$ & Proportion (\%) & $\begin{array}{l}\text { Cumulative } \\
\text { proportion (\%) }\end{array}$ \\
\hline \multicolumn{5}{|c|}{ Dependent variables } \\
\hline 1 & 0.505 & 0.505 & 0.274 & 0.274 \\
\hline 2 & 0.334 & 0.839 & 0.180 & 0.454 \\
\hline \multicolumn{5}{|c|}{ Independent variables } \\
\hline 1 & 0.792 & 0.792 & 0.189 & 0.189 \\
\hline 2 & 0.158 & 0.950 & 0.122 & 0.311 \\
\hline
\end{tabular}

in the individual original dependent variables. Also, the dependent canonical variable predicts 83.9 per cent of the variance in the individual original dependent variables.

To conclude, the canonical redundancy analysis provides evidence that the first and second canonical variables are relatively good overall predictors of the opposite set of variables, with cumulative proportions being 45.4 and 31.1 per cent.

For validation purposes, the authors ran a canonical correlation analysis on an analysis and hold-out sample. Canonical weights were compared across the two samples, thereby providing an indication of the stability of this measure for the combined sample. Those results lead to the acceptance of the research hypothesis.

\section{Discussion and implications}

The purpose of the study was to investigate the way in which the MrkIS effectiveness dimensions and $\mathrm{MO}$ dimensions are related, and the strengths and the nature of these relationships. Canonical correlation analysis gives us the opportunity to combine into a composite measure what otherwise might be an unmanageably large number of bivariate correlations between sets of variables. Results lead to the acceptance of the research hypothesis and demonstrate some interesting implications.

The research results indicate that MO and MrkIS effectiveness are related concepts. This is important because it demonstrates the necessity to consider the MO when determining either the antecedents or the consequences of MrkIS effectiveness within an integrated conceptual model.
Another interesting finding from this study is that not all dimensions of MO have an equally strong relationship with all dimensions of an MrkIS's effectiveness. In fact, these are the first empirical data that demonstrate a strong relationship between the customer and competitor orientation dimensions of the MO concept with the marketing procedural improvement and the two external dimensions of MrkIS effectiveness, namely customer knowledge and market responsiveness (first canonical function). This finding is important because it empirically justifies the need to tie together, at the strategic level, the decision to invest in developing an MrkIS with the decision to increase the company's market centricity. In other words, the findings from this study mark the path towards a virtuous cycle that helps companies to develop, sustain and increase their market focus by ensuring simultaneous development of the customer and competitor orientation with investment in MrkIS that have clearly defined objectives regarding the system's contribution in terms of corporate customer knowledge, market responsiveness and procedural improvements.

Also, without entirely resolving the issue, the findings from the first canonical function show that market centricity (customer and competitor orientation) relates to the company's internal environment (marketing procedural improvements). The need for aligning the company's internal environment with the marketing strategy's objectives has been raised before in the marketing literature $^{75}$ but the empirical research in this direction remains $\operatorname{sim} .^{76}$ The relationship between 
the contribution of the company's MrkIS in terms of marketing procedural improvements with customer and market orientation tallies with this view.

The significance of the company's internal environment with regard to the company's ability to become market-led is further demonstrated by the findings of the second canonical function. This study clearly demonstrates that the company's ability to coordinate the efforts of the various functions and align them with the needs of the company's customers (interfunctional coordination) relates to the ability of the company's MrkIS to provide the employees of the marketing function with the appropriate informational support. In fact, the second canonical function reveals the path to a second virtual cycle that is mainly internal in nature. This second leg of market centricity shows that companies investing to increase their market orientation, have to develop their abilities to coordinate the efforts of the different functions to meet the conditions of the market and the needs of the customers. To achieve this, it helps significantly to also invest in MrkIS that offer the employees of the marketing department all necessary information that will facilitate this task.

These findings are also interesting for practitioners. The major practical contribution from the study is that the effort to become more market focused goes hand in hand with an investment to appropriate MrkIS. This study shows that missing the right informational foundation is a strong deterrent in the company's effort to become more competitive in responding to customers' needs. Hence, companies seeking to increase their MO have to invest in developing the necessary MrkIS. Nevertheless, top management should not ignore the reverse reading of this study. Investing in strong, powerful and, possibly, more expensive MrkIS makes little sense unless the company's service strategy is oriented towards excellence in meeting and satisfying customers' needs. In other words, the findings from this study show managers the need to keep their MrkIS in balance with their corporate strategy and to invest accordingly.
Furthermore, managers have to understand that MO gives to the company the 'way of thinking' and thus, the way to apply effectively all of these MrkIS tools with the potential to add real value to the relationship with the customer. On the other hand, the marketing information provided by MrkIS through the firm's forms leads executives to gain customer knowledge and to increase internal communication and market responsiveness, which, consequently, result in developing and implementing effective market-oriented efforts and marketing strategies in general.

\section{LIMITATIONS}

As with many studies, there are some limitations inherent with this study. The first limitation pertains to the sample of the study. The research involved luxury and 5-star hotels in Greece. Thus, the findings could not be generalised to other countries or other types of hotels. Future research should be undertaken in order to investigate the relationship between the two constructs in other countries and among different types of hotels. In addition, this study is confined to the hotel industry only. Thus, future research is certainly required before the relationships this study reveals can be applied to other industries.

Furthermore, this study looked at the MrkIS effectiveness of a hotel at one moment in time. Any MrkIS develops over time, both as a result of experience and because of the fast development of MrkIS technology. Future research may explore the necessary conditions under which MrkIS effectiveness and MO relationships could prevail over time. ${ }^{77}$

\section{References}

1 Talvinen, J. M. (1995) 'Information systems in marketing. Identifying opportunities for new applications', European Journal of Marketing, Vol. 29, No. 1, pp. 8-26.

2 Wierenga, B., Van Bruggen, G. H. and Staelin, R. (1999) 'The success of marketing management support systems', Marketing Science, Vol. 18, No. 3, pp. 196-207.

3 Talvinen, J. M. and Saarinen, T. (1995) 'MrkIS support for the marketing management process: Perceived improvements for marketing management', Marketing Intelligence \& Planning, Vol. 13, No. 1, pp. 18-27.

4 Wierenga, B. and Ophuis, O. P. (1997) 'Marketing decision support systems: Adoption, use, and satisfaction', International Journal of Research in Marketing, Vol. 14, No. 3, pp. 275-290. 
5 Burke, R. R., Rangaswamy, A., Wind, J. and Eliashberg, J. (1990) 'A knowledge-based system for advertising design', Marketing Science, Vol. 9, No. 3, pp. 212-229.

6 Sisodia, R. S. (1992) 'Marketing information and decision support systems for services', The Journal of Services Marketing, Vol. 6, No. 1, pp. 51-64.

7 Van Hoof, H. B., Verbeeten, M. J. and Combrink, T. E. (1996) 'Information technology revisited: International lodging-industry technology needs and perceptions: A comparative study', The Cornell Hotel and Restaurant Administration Quarterly, Vol. 37, No. 6, pp. 86-91.

8 Van Bruggen, G., Smidts, A. and Wierenga, B. (1998) 'Improving decision making by means of a marketing decision support system', Management Science, Vol. 44, No. 5, pp. 644-658.

9 Fesenmaier, D. R., Leppers, A. W. and O'Leary, J. T. (1999) 'Developing a knowledge-based tourism marketing information system', Information Technology and Tourism, Vol. 2, No. 1, pp. 31-44.

10 Colgate, M. (2000) 'Marketing and marketing information system sophistication in retail banking', Service Industries Journal, Vol. 20, No. 1, pp. 139-152.

11 Raymond, L., Julien, P. A. and Ramangalahy, C. (2001) 'Technological scanning by small Canadian manufacturers', Journal of Small Business Management, Vol. 39, No. 2, pp. 123-138.

12 Panigyrakis, G. and Chatzipanagiotou, K. (2004) 'The relationship between market orientation and marketing information systems effectiveness: An empirical instigation', Review of Business Information Systems, Vol. 8, No. 4, pp. 69-82.

13 Cox, D. F. and Good, R. E. (1967) 'How to build a marketing information system', Harvard Business Review, Vol. 45, No. 3, pp. $145-154$.

14 Säksjärvi, M.V.T. and Talvinen, J. M. (1993) 'Integration and effectiveness of marketing information systems', European Journal of Marketing, Vol. 27, No. 1, pp. 64-77.

15 Soanes, C. and Stevenson, A., (eds) (2005) 'Oxford Dictionary of English, 2nd edn, Oxford University Press, Oxford.

16 Gounaris, S., Panigyrakis, G. and Chatzipanagiotou, K. (2007) 'Measuring the effectiveness of marketing information systems: An empirically validated instrument', Marketing Intelligence \& Planning, Vol. 25, No. 6, pp. 612-631.

17 Grover, V., Jeong, S. R. and Segars, A. H. (1996) 'Information systems effectiveness: The construct space and patterns of application', Information and Management, Vol. 31, No. 4, pp. 177-191.

18 Burke James, F. (1986) 'Computerize management of tourism marketing information', Tourism Management, Vol. 7, No. 4, pp. 279-289.

19 Van Bruggen, G. H. (1993) 'The Effectiveness of Marketing Management Support Systems', Eburon Publishers, Delft.

20 Stipanuk David, M. (1993) 'Tourism and technology: Interactions and implications', Tourism Management, Vol. 14, No. 4, pp. 267-278.

21 O'Brien, T. V., Schoenbachler, D. D. and Gordon, G. L. (1995) 'Marketing information systems for consumer products companies: A management overview', Journal of Consumer Marketing, Vol. 12, No. 5, pp. 16-36.

22 Van Bruggen, G. H., Smidts, A. and Wierenga, B. (1996) 'The impact of the quality of a marketing decision support system: An experimental study', International Journal of Research in Marketing, Vol. 13, No. 4, pp. 331-344.

23 Van Bruggen, G., Smidts, H. and Wierenga, B. (2001) 'The powerful triangle of marketing data, managerial judgment, and marketing management support systems', European Journal of Marketing, Vol. 35, No. 7/8, pp. 796-816.

24 Mayros, V. and Dolan, D. J. (1988) 'Hefting the data load: How to design the MrkIS that works for you', Business Marketing, Vol. 73, No. 3, pp. 47-69.

25 Marshall, K. P. and La Motte, S. W. (1992) 'Marketing information systems: A marriage of systems analysis and marketing management', Journal of Applied Business Research, Vol. 8, No. 3, pp. 61-73.

26 Ritchie Robin, J. B. and Brent Ritchie, J. R. (2002) 'A framework for an industry supported destination marketing information system', Tourism Management, Vol. 23, No. 5, pp. 439-454.

27 Huo, Y. (1998) 'Information technology and the performance of the restaurant firms', Journal of Hospitality and Tourism Research, Vol. 22, No. 3, pp. 239-251.

28 Siguaw, J. A, Enz, C. A and Namasivayam, K. (2000) 'Adaptation of information technology in US hotels: Strategically driven objectives', Journal of Travel Research, Vol. 39, No. 2, pp. 192-201.

29 Namasivayam, K., Enz, C. A. and Siguaw, J. A. (2000) 'How wired are we? Selection and use of new technology in US hotels', The Cornell Hotel and Restaurant Administration Quarterly, Vol. 41, No. 6, pp. 40-48.

30 Nykiel, R. A. (2001) 'Technology, convenience and consumption', Journal of Hospitality and Leisure Marketing, Vol. 7, No. 4, pp. 79-84.

31 Kitchen, P. J. and Dawes, J. F. (1995) 'Marketing information systems in smaller building societies', International Journal of Bank Marketing, Vol. 13, No. 8, pp. 3-9.

32 Xu Xianzhong, M. (1999) 'The strategic orientation of marketing information systems - An empirical study', Marketing Intelligence \& Planning, Vol. 17, No. 6, pp. 262-271.

33 Hee, C. H. and Keynog, K. J. (1998) 'Determination of information system development priority using quality function development', Computers \& Industrial Engineering, Vol. 35, No. 1/2, pp. 241-244.

34 Barcheldor, B. (1999) 'Hospitality and travel: A trip to Grandma's goes high tech', Information Week, p.189.

35 Holtz, H. (1992) 'Data-based Marketing', John Wiley and Sons, New York.

36 Narver, J. C. and Slater, S. F. (1990) 'The effect of market orientation on business profitability', Journal of Marketing, Vol. 54, pp. 20-35.

37 Hooley, G., Lynch, J. E. and Shepherd, J. (1990) 'The marketing concept \pm putting the theory into practice', European Journal of Marketing, Vol. 24, No. 9, pp. 7-23.

38 Deshpande, R., Farley, J. U. and Webster, F. (1993) 'Corporate culture, customer orientation, and innovativeness in Japanese firms: A quadrad analysis', Journal of Marketing, Vol. 57, No. 1, pp. 23-37.

39 Deng, S. and Dart, J. (1994) 'Measuring market orientation: A multi-factor, multi-items approach', Journal of Marketing Management, Vol. 10, pp. 725-742.

40 Diamantopoulos, A. and Hart, S. (1993) 'Linking market orientation and company performance: Preliminary work on Kohli and Jaworski's framework', Journal of Strategic Marketing, Vol. 1, No. 2, pp. 93-122.

41 Greenley, G. E. (1995a) 'Forms of market orientation in UK companies', Journal of Management Studies, Vol. 32, No. 1, pp. 47-66.

42 Kohli, A. J. and Jaworski, B. J. (1990) 'Market orientation: The construct, research propositions and managerial implications', Working Paper, Marketing Science Institute, Cambridge, MA. 
43 Day, G. S. (1994) 'The capabilities of market-driven organizations', Journal of Marketing, Vol. 58 (October), pp 37-52.

44 Tuominen, M. and MoÈller, K. (1996) "Market orientation: a state of the art review", in Beracs, J., Bauer, A. and Simon, J. (Eds), Marketing for an Expanding Europe, 25th EMAC Conference, 14-17 May, Budapset, Hungary, pp. 1161-1181.

45 Sinkula, J. M. (1994) 'Market information processing and organizational learning', Journal of Marketing, Vol. 58, No. 1, pp. 35-45.

46 Day, G. S. and Wensley, R. (1988) 'Assessing advantage: A framework for diagnosis competitive superiority', Journal of Marketing, Vol. 52, pp. 1-20.

47 Aaker, D. A. (1988) 'Strategic Market Management, 2nd edn, Wiley, New York.

48 Porter, M. (1980) 'Competitive Strategy', Free Press, New York.

49 Porter, M. (1985) 'Competitive Advantage', Free Press, New York.

50 Narver, J. D., Slater, S. F. and Tietje, B. (1998) 'Creating a market orientation', Journal of Market-Focused Management, Vol. 2, No. 3 , pp. 241-256.

51 Hart, S. and Diamantopoulos, A. (1993) 'Linking market orientation and company performance: Preliminary work on Kohli and Jaworski's framework', Journal of Strategic Marketing, Vol. 1, No. 2, pp. 93-122.

52 Siguaw, J. A. and Diamantopoulos, A. (1995) 'Measuring market orientation: Some evidence on Narver and Slater's three component scale', Journal of Strategic Marketing, Vol. 3, pp. 77-88.

53 Hunt, S. D. and Morgan, R. M. (1995) 'The comparative advantage theory of competition', Journal of Marketing, Vol. 59 (April), pp. 1-15.

54 Wrenn, B. (1997) 'The market orientation construct: Measurement and scaling issues', Journal of Marketing Theory and Practice, Vol. 5, No. 3, pp. 31-54.

55 Baker, W. E. and Sinkula, J. M. (1999) 'The synergistic effect of market orientation and learning orientation on organizational performance', Journal of Academy of Marketing Science, Vol. 27, No. 4, pp. 411-427.

56 Shaw, R. (1994) 'How to Transform Marketing through IT', Business Intelligence, London.

57 Hewson, W. and Wilson, H. (1994) 'Exploring the alignment of information technology investments with sales and marketing strategies, Proceedings of the British Academy Management Conference, University of Lancaster, 12-14 September.

58 Gorski, D. (1995) 'The Marketing Data Base, the Gower Handbook of Marketing, 4th edn, Gower Publishing Company, London.

59 ICAP Greek Hotel Directory (2004) 'TourismICAP, available at: www.icap.gr.
60 Brick, J.M. and Bose, J. (2005) 'Analysis of potential nonresponse bias, Proceedings of the Survey Methodology Section, American Statistical Association, Alexandria, VA.

61 Armstrong, S. J. and Overton, T. S. (1977) 'Estimating nonresponse bias in mail surveys', Journal of Marketing Research, Vol. 14, No. 3, pp. 396-402.

62 Stevens, J. (1996) 'Applied Multivariate Statistics for the Social Sciences, 3rd edn, Lawrence Erlbaum Associates, Mahwah, NJ.

63 Fornell, C. and Larcker, D. F. (1981) 'Evaluating structural equation models with unobservable variables and measurement error', Journal of Marketing Research, Vol. 18, No. 1, pp. 39-50.

64 Joreskog, K. G. and Sorbon, D. (1993) 'LISREL 8: Structural Equation Modelling with the Simplis Command Language', Lawrence Erlbaum Associates, Hillsdale, NJ.

65 Sharma, S. (1996) 'Applied Multivariate Techniques', John Wiley \& Sons, Inc., New York.

66 Cronbach, L. J. (1951) 'Coefficient alpha and the internal structure of tests', Psychometrika, Vol. 16, pp. 297-333.

67 Gray, B., Matear, S., Boshoff, C. and Matheson, P. (1998) 'Developing a better measure of market orientation', European Journal of Marketing, Vol. 32, No. 9/10, pp. 884-903.

68 Hooley, G. J., Cox, T., Fahy, J., Shipley, D., Beracs, J., Fonfara, K. and Snoj, B. (2000) 'Market orientation in the transition economies of central Europe: Tests of the Narver and Slater market orientation scales', Journal of Business Research, Vol. 50, No. 3, pp. 273-285.

69 Hair, F. J., Anderson, R. E. and Tatham, R. L. (1992) 'Multivariate Data Analysis with Readings', Macmillan Publishing Company, New York, NY.

70 Thompson, B. (1984) 'Canonical Correlation Analysis: Uses and Interpretation', Sage Publications, Thousand Oaks, CA, Quantitative Applications in the Social Sciences Series (47).

71 Kotz, S. and Johnson, N. L. (1982/1988) 'Encyclopedia of Statistical Sciences, Vols. 1-9, Wiley, New York.

72 Norusis, M. J. (1998) 'SPSS 6.1: Guide to Data Analysis', Prentice-Hall, New Jersey.

73 Hair, J. F., Anderson, R. E., Tatham, R. L. and Black, W. C. (1998) 'Multivariate Data Analysis, 5th edn, Prentice-Hall, New Jersey.

74 Stewart, D. and Love, W. (1968) 'A general canonical correlation index', Psychological Bulletin, Vol. 70, No. 2, pp. 160-163.

75 Piercy, N. F. (1995) 'Customer satisfaction and the internal market: Marketing our customers to our employees', Journal of Marketing Practice: Applied Marketing Science, Vol. 1, No. 1, pp. 22-44.

76 Gounaris, S. (2008) 'The notion of internal market orientation and employee job satisfaction: Some preliminary evidence', Journal of Services Marketing, Vol. 22, No. 1, pp. 68-90. 


\section{Appendix}

See Table A1.

Table A1: MrklS effectiveness instrument: confirmatory

\begin{tabular}{|c|c|c|c|c|c|}
\hline $\begin{array}{l}\text { Goodness-of-fit measures: } \mathrm{GFI}=0.913, \mathrm{AGFI}=0.901 \text {, } \\
\mathrm{CFI}=0.971 \text {, RMSEA }=0.076\end{array}$ & $\begin{array}{l}\text { Standardised } \\
\text { regression } \\
\text { weights }\end{array}$ & AVE & $\begin{array}{l}\text { Convergent } \\
\text { validity }\end{array}$ & (Corr) $^{2}$ & $\begin{array}{l}\text { Discriminant } \\
\text { validity }\end{array}$ \\
\hline \multicolumn{6}{|l|}{ Marketing procedural improvements } \\
\hline Improved marketing efforts control & $0.887^{\star}$ & 0.644 & Yes & 0.467 & Yes \\
\hline Improved marketing actions planning & $0.957^{*}$ & & & & \\
\hline Improved marketing reporting & $0.546^{\star}$ & & & & \\
\hline Improved marketing decision making & $0.614^{*}$ & & & & \\
\hline \multicolumn{6}{|l|}{ Employees support } \\
\hline Time saving, lower level of marketing routine work & $0.797^{\star}$ & 0.658 & Yes & 0.646 & Yes \\
\hline Improved sales work and customer service & $0.915^{\star}$ & & & & \\
\hline Improved internal communication & $0.807^{\star}$ & & & & \\
\hline \multicolumn{6}{|l|}{ Customer knowledge } \\
\hline Improved market sensitivity & $0.898^{*}$ & 0.727 & Yes & 0.547 & Yes \\
\hline Improved customer satisfaction & $0.799^{\star}$ & & & & \\
\hline Improved sales & $0.910^{*}$ & & & & \\
\hline Improved customer knowledge & $0.867^{\star}$ & & & & \\
\hline \multicolumn{6}{|l|}{ Market responsiveness } \\
\hline Marketing programmes cost savings & $0.807^{\star}$ & 0.734 & Yes & 0.614 & Yes \\
\hline Quickest development of new services in the market & $0.958^{*}$ & & & & \\
\hline Improved sales promotion activities & $0.939^{\star}$ & & & & \\
\hline Direct and more effective marketing research & $0.879^{\star}$ & & & & \\
\hline Marketing procedural improvements employee support & $0.624^{*}$ & & & & \\
\hline $\begin{array}{l}\text { Marketing procedural improvements customer } \\
\text { knowledge }\end{array}$ & $0.684^{*}$ & & & & \\
\hline $\begin{array}{l}\text { Marketing procedural improvements market } \\
\text { responsiveness }\end{array}$ & $0.639^{*}$ & & & & \\
\hline Employee support customer knowledge & $0.804^{*}$ & & & & \\
\hline Employee support market responsiveness & $0.740^{\star}$ & & & & \\
\hline Customer knowledge market responsiveness & $0.784^{*}$ & & & & \\
\hline
\end{tabular}

$\mathrm{AVE}=$ average variance extracted $=\Sigma(\text { standard loadings })^{2} / \Sigma(\text { standard loadings })^{2}+\Sigma \varepsilon_{i j}$, Conv $=$ convergent validity $($ AVE $>0.50)$, discriminant validity $=\mathrm{AVE} /\left(\right.$ Corr $\left.^{2}\right)>1,(\text { Corr })^{2}=$ highest correlation between the examined factor and the rests of factors.

*significant $p=0.000$. 